\title{
The Place and Significance of the Old Roman Institute of the "Lex Rhodia de iactu" in the Czech Civilian Tradition
}

\author{
Petr Dostalík ${ }^{*}$
}

\begin{abstract}
The article deals with the issue of a so-called lex Rhodia de iactu in Roman and modern law. The article describes the lex Rhodia de iactu as an example of the reception of Greek. law into Roman law. The article considers the reception of the principle of Rhodian Law in the Pandekt law and in the modern Czech private law. It looks the proper place and meaning of this institute within the most recent $C_{z}$ zech Civil Code.
\end{abstract}

\section{Keywords}

Lex Rhodia de iactu, versio in rem; actio negotiorum gestio utilis; Extreme Emergency; Unjust Enrichment.

\section{Introduction}

As part of the reception process, the various institutes of Roman law are applied in the new legal order in the spirit or in the intentions of Roman law. The case of such a successful reception of a particular institute of Roman Law is the takeover of possession (possessio) into modern French, German and Austrian law. ${ }^{1}$ They can be taken not only by the institutes but also by the principles that will become the basis for the creation of new legal institutions and the courts can rely on such a principle in their decisionmaking activities. An example of a successful reception of such a principle of Roman law is the principle no one can enrich itself at the expense of another. ${ }^{2}$

However, some principles and institutions of Roman law become part of a new, modern civil law in an altered form. The texts of the Roman lawyers that are contained in the Corpus Iuris Civilis, could be interpreted differently by the lawyers of the ius commune.

* Doc. JUDr. Petr Dostalík, Ph.D., Katedra teorie práva a právních dějin, Právnická fakulta, Univerzita Palackého, Olomouc / Department of Theory of Law and Legal History, Faculty of Law, Palacký University, Olomouc, Czech Republic / E-mail: petr.dostalik2007@gmail.com / ORCID: 0000-0003-4457-8130

1 BLAHO, P. et al. Dř̌ba v rímskom a kánonickom práve [Possession in the Roman and Canonical Law]. Praha: Leges, 2019; HAUSMANNINGER, H. Nemo sibi causam possessionis mutare potest - eine Regel des Veteres in der Diskussion des Klassikers. In: SÉIDL, E. (ed.). Aktuelle Fragen aus Modernem Recht und Rechtsgeschichte, Gedachtnisschrift fur Rudolf Schmidt. Berlin, 1966, p. 399; WONNACOT, M. Possession of Land. Cambridge: Cambridge University Press, 2006; LINK, M. Possession, Possessio und das Schickal des Common Law. Frankfurt am M., 2003; ZWALVE, W. and B. SIRKS. Grundzüge der europeischen Privatrechtgeschichte: Einfiubrung und Sachenrecht. Wien, 2012; LÉVY, J.- P. Histoire de la propriété. Paris, 1972; GORDLEY, J. and U. MATTEI. Protection Possession. The American Journal of Comparative Law, 1996, no. 44, pp. 293-334.

2 D. 12.6.14. 
In the writings of those lawyers the institutes are updated and adapted to the needs of modern, industrial society. If the institute is understood differently, we can now talk about the "second life" of such an institute of Roman Law. The aim of this article is to show that, even in the new Czech Civil Code, there are such institutes, which have been taken from Roman law, but are understood differently and thus causes considerable interpretative difficulties to a legal theory and legal practice. As an example of such an institute was elected \3014 OZ 2012. The institute is a direct descendant of the Roman lex Rhodia de iactu. ${ }^{3}$

\section{Lex Rhodia in Roman Law}

The second title of the Fourteenth book of Digest, entitled De lege Rhodia de iactu has a special status within Corpus Iuris Civilis. The entire legal adaptation that relates to D. 14.2 is based on the same legal principle: no one can enrich at the expense of another. ${ }^{4}$ If the goods of one of the merchants were thrown out of the ship to reduce the load on the ship and thus save the goods of other merchants traveling on the same ship, then the merchants whose goods were saved would gain an unfair property advantage compared to those, whose goods were sacrificed. Lex Rhodia de iactu is an interesting institute for several other reasons:

Firstly, it is an example of the ancient reception of one law institute with one legal order into another order (no matter how the extent as well as the reception nature itself is being in question in jurisprudence).

Secondly, the principle of compensation for the individual's things sacrificed in the interest of mutual benefit was so inspirational that it influenced the later legal thinking and we can find application of this principle both in modern civil law (including the new Czech Civil Code from 2012 (Act no. 89/2012, further referred as OZ 2012 - see \ 3012 of this Code) $)^{5}$ and private international law (issues of so-called collective river accidents).

3 This paper represents an elaborated and extended version of the article published in the Czech language, which was concerned about the influence of the Roman Law upon maritime law: DOSTALÍK, P. and B. POLÁČEK. Lex Rhodia de iactu a společná havárie [Lex Rhodia iactu and the General Average]. Právněbistorické studie, 2017, Vol. 47, no. 1, pp. 5-16. To this influence see also RÜŽIČKA, K. et al. Vliv rímskébo práva na vybrané instituty práva mezinárodníbo obchodu [Evolution of Codification of Private International Law. Private Law Regulation of International Relations]. Praha: Wolters Kluwer, 2018.

4 D. 12.6.66 and D. 50.17.206. Iure naturae aequum est neminem cum alterius detrimento et iniuria fieri locupletiorem. About interpretation and application of this legal principle see DOSTALÍK, P. Condictiones. Ke kořenuim bezdîvodnébo obohacení [Condictiones. To the Roots of Unjust Enrichment]. Praha: Auditorium, 2018, p. 130; See also LIEBS, D. The History of Roman Condictio up to Justinian. In: MacCORMICK, N. and P. BIRKS (eds.). Legal Mind. Essays for Tony Honore. Oxford: Clarendon Press, 1986, s. 163-185; HONORE, A. M. Condictio and Payment. In: Acta iuridica, 1958, no. 1, s. 135-140.

5 The English translation available at: https://www.cak.cz/assets/pro-advokaty/mezinarodni-vztahy/ civil-code.pdf 
Lex Rhodia is often mentioned as one of the examples of so-called Roman commercial law. ${ }^{6}$ In its essence, it is the oldest maritime insurance. ${ }^{7}$

Thirdly, within the legal issues related to Rhodian law, Roman lawyers came to a solution that substantially influenced other issues of private law, such as the question of abandoning the subject.

\subsection{Lex Rhodia as reception of Greek law}

In Lex Rhodia, there is very often sighted the influence of Greek law on Roman law (by name). ${ }^{8}$ However, this is not in accordance with the Romans' attitude towards foreign law. For example, M. T. Cicero praises the supremacy of Roman law. If the Roman law is perfect, then there is no reason to use foreign advice. However, even in the present legal science, there exist more objections against the formal reception of Greek law. Some scholars object that such a reception is incompatible with the spirit that dominates in the closed world of the ancient city. ${ }^{9}$ This closeness is reflected especially in the rule of law, which is considered as the inviolable heritage of the people, the heritage as inviolable as religion. Nevertheless, considering importance of Greece in influencing the antique maritime trade and due to the close cultural contact between Greece and Rome, it is possible to regard the use of foreign maritime and trade habits, commonly known as Lex Rhodia de iactu. Against the reception of Greek law, there are often objections brought the Roman legal sources refer to the island of Rhodes only in D. 14.2. And from this whole, not very large title, only two fragments contain explicit mention of the island of Rhodes. These are fragments of D. 14.2.2 and D. 14.2.9. The first fragment comes from the lawyer Paul and describes the general principle of the Rhodian law. The second fragment is attributed to Volusi Maecian, the lawyer from the era of Mark Aurelius and Antonio Pius, and is an excerpt from the work called Ex lege Rhodia.

There was also a doubt concerning authenticity of the work, as this work is not mentioned in the list of works cited in the Florentine Index. The extract evokes the marine accident hypothesis and the shipmaster's request directed to the Emperor Antonius who replies that the law on the sea where Lex Rhodia is applied does not conflict with the applicable law. Maenacius adds that Augustus had already decided in the same sense.

6 HUVELIN, P. Etudes d'bistoire du droit commercional romain. Histoire externe - droit maritime. Paris, 1929, p. 127.

7 AUBERT, J.-J. Dealing with the Abyss. The Nature and Purpose of the Rhodian Sea-Law on Jettison (Lex Rhodia de iactu, D. 14.2) and the Making of Justinian's Digest. In: CAIRNS, John W. and Paul du PLESSIS (eds.). Beyond Dogmatics. Law and Society in Roman World. Edinburgh: Edinburgh University Press, 2007, p. 157, Edinburgh studies in law.

8 To this influence see DOSTALÍK, P. Recká filosofie a jeji vliv na řmskou práuni védu [Greek Philosophy and its Influence Upon the Roman Legal Science]. Olomouc, 2012, pp. 49-76.

9 MARTINO, F. Lex Rhodia. In: Dirrito e sociéta nell'antica Roma II. Roma: 1982, pp. 72-147. 
Some of modern authors $\left(\right.$ Wagner $\left.^{10}\right)$ limit the scope of application the Rhodian rules only to plundering of a shipwreck site, or to duty exemption applicable to those ships blown up to a port by the storm. These controversies lead to denial of the Greek and Rhodian origin of "Rhodian law." Critics view this title as the law, created by "a posteriori" compilers, that the Rhodian law was created of in the 8th century AD.

Classical Roman law therefore, according to this extreme critique, was developed autonomously, even in the field of maritime law, without taking over the foreign legal institutes. ${ }^{11}$ However, we consider as proved that Roman law accepted the habits of Greek maritime merchants ${ }^{12}$, that were in use in the eastern Mediterranean, and that these habits were named in honour of the famous Greek island by the compilers of the Corpus Iuris Civilis. Adoption of the "Rhodian Law" was done through the adoption of provisions on the common danger and obligation of contributing to contracts for the transportation, hire and sale of goods by Roman merchants, and subsequently by interpretation of these contracts by the Roman authorities, particularly the Praetor. Roman law also refers to a provision in the contract as a lex. The thesis that the Rhodian law was accepted by the Emperor Augustus and confirmed by the Emperor Antonius seems unlikely. ${ }^{13}$

\subsection{Principle of the Rhodian Law}

The basic principle of the Rhodian law is given in the fragment

D. 14.2.1. Paulus libro secundo sententiarum.

Lege rodia [rhodia] cavetur, ut si levandae navis gratia iactus mercium factus est, omnium contributione sarciatur quod pro omnibus datum est.

"It is provided by the Rhodian Law that where merchandise is thrown overboard for the purpose of lightening a ship, what has been lost for the benefit of all must be made up by the contribution of all." 14

What led the Romans to accept this principle? It is likely that the Romans tried to adapt to the habits that dominated the maritime trade in the Mediterranean. Among other things, these habits focus on the basic aspect. This is a fair legal regulation on the consequences of unpredictable sea dangers that endanger human life, including the risk of wreckage, pirates raid, and frequent injuries and losses on property on the sea routes. The Roman lawyers of the classical period considered unfair that all those who would benefit from the salvage of the ship would not participate in the salvage. This is evidenced by the lawyer Hermogenian's reference to aequitas.

10 WAGNER, H. Die lex Rhodia de iactu. Revue internationale des droits de l'Antiquité, 1997, no. 44, pp. 357-380.

11 ASHBURNER, W. The Rhodian Sea Law. Aalen, 1975, passim.

12 CHEVREAU, E. La Lex Rhodia de iactu. Un exemple de la reception d'une Institution Étrangére dans le droit romain. Tijdschrift voor Rechtsgeschiedenis 2005, Vol. 73, no. 1-2, pp. 67-80.

13 Ibid., p. 70 .

14 The English translation of Digest comes always from SCOTTS, S. P. The Digest or Pandects of Justinian. Cincinati, 1932. 
D. 14.2.5 pr. Hermogenianus libro secondo iuris epitomarum

Amissae navis damnum collationis consortio non sarcitur per eos, qui merces suas naufragio liberaverunt: nam huius aequitatem tunc admitti placuit, cum iactus remedio ceteris in communi periculo salva navi consultum est.

"The contribution of those who saved their merchandise from shipwreck does not indemnify anyone for the loss of the vessel; for it is held that the equity of this contribution is only admitted when, by the remedy of jetsam, during the common danger, the interest of the others is consulted, and the ship is saved." 15

However, there should be noted that the Romans were led to the recognition of the Rhodian law by very practical need. If the Romans did not recognize this principle based on aequitas, no one would want to trade with them. Thus, Roman law had to deal with changed social conditions - Roman lawyers had to make this obligation part of the Roman legal code.

The following fragment shows how Rhodian law is applied:

D. 14.2.2 pr. Paulus libro trigensimo quarto ad edictum

Si laborante nave iactus factus est, amissarum mercium domini, si merces vehendas locaverant, ex locato cum magistro navis agere debent: is deinde cum reliquis, quorum merces salvae sunt, ex conducto, ut detrimentum pro portione communicetur, agere potest. servius quidem respondit ex locato agere cum magistro navis debere, ut ceterorum vectorum merces retineat, donec portionem damni praestent. immo etsi ${ }^{\wedge}$ non^ retineat merces magister, ultro ex locato habiturus est actionem cum vectoribus: quid enim si vectores sint, qui nullas sarcinas habeant? Plane commodius est, si sint, retinere eas. at si non totam navem conduxerit, ex conducto aget, sicut vectores, qui loca in navem conduxerunt: aequissimum enim est commune detrimentum fieri eorum, qui propter amissas res aliorum consecuti sunt, ut merces suas salvas haberent.

"If the merchandise was jettisoned from the ship, which was in trouble, the owners of that merchandise, if they delivered the merchandise to the transportation, should sue the captain of the ship on the base of the action of the contract of lease. And captain can use the very same action against the other passengers, for the reason that their merchandise had been saved, so they have to contribute. And Servius responded that they should sue the captain by the same action to hold the merchandise of the other passengers on the board of the ship until they will contribute. But if the captain would have not retain the merchandise on board, he is still able to use the action of the contract of lease against the passengers. What is to be done if there are passengers who have no baggage? It evidently will be more convenient to retain their baggage, if there is any; but if there is not, and the party has leased the entire ship, an action can be brought on the contract, just as in the case of passengers who have rented places

15 In the contemporary Czech legal science is this question recently really disputed. See also DOSTALÍK, P. Condictiones. Ke korenum bezdiovodného obohacení [Condictiones. To the Roots of Unjust Enrichment]. Praha: Auditorium, 2018, p. 121; MELZER, F. et al. Občanský zákoník. \ 2894-3081. Velký komentár [Civil Code. Grand Commentary]. Praha: Leges, 2018, pp. 1425-1426; TICHÝ, L. Bezdůvodné obohacení. Základní pojmy a návrh občanského zákoníku [Unjust Enrichment. Basic Notions and the Draft of Civil Code]. Bulletin advokacie, 2011, no. 5, p. 15. 
on a ship; for it is perfectly just that the loss should be partially borne by those who, by the destruction of the property of others, have secured the preservation of their own merchandise."

The observed method "application of the Rhodian principle" is very interesting. Roman law did not adapt the obligation to contribute to a maritime accident but, on the contrary, uses the Roman legal code, thus attempting to implement this principle by its own means. From possible contract types, Paulus is choosing locatio-conductio, a bilateral contract based on good faith, which was chosen because it is a contract used in maritime transport. One of the contract parties called vector, entrusts cargo to the ship's captain for transport to determined destination, for the specified sum or for the part of goods. This is locatio operis faciendi where vector is the locator and magister navis the conductor. ${ }^{16}$ J. Klíma emphasizes the different view that Roman jurisprudence viewed provisions of the Rhodian law:

"The Institute of Rhodian Law is viewed as locatio conductio. Carriers, whose merchandise was thrown into the sea, were given actio locati against the captain to compensate the sustained damage. The captain had actionem conducti against those carriers whose goods remained intact, and at the same time he had retention right for the saved goods." 17

Pernice says that the Roman jurists made the need a virtue. ${ }^{18}$ As he notes "Vectores do not stand against each other in any legal relationship, after executing iactus they cannot sue each other, but they concluded a transport contract with the captain. Therefore, the injured vector sues the captain for the damage compensation, the captain then sues the carriers whose goods was saved for the contribution payment. Therefore, the sue of rental relation has an unusual content. But it is given by law." 19

We emphasize that Roman lawyers have fundamentally modified a contract for work a legal relationship exists only between the captain and the injured passenger on the one hand, and the captain and the passengers whose goods were not thrown away on the other hand. Only the captain is a party dealing with the other passengers' mercantile consortium (consortium) which is created on the ship, only he has a contractual relationship with each of vectores. Therefore, he is the only one able to mediate the contribution payment between individual, no connected vectores.

All this corroborates the fact that only the adaptation of principle of the contribution for thrown out things into Roman law itself, was done on the base of aequitas. These contributions are paid by the owners whose goods were saved because the other ones' goods were thrown into the sea. This is the contrast with the Greek law, which permits

16 Some authors, e.g. CANNATA, C. A. La disavventure del Capitano J. P. Vos. Labeo, 1995, no. 41, p. 390, who considers it to be locatio conductio rei vehendae, as, in their opinion, at the sea transport the issue is not an opus according to the definition from Digest (D. 50.16.5.1).

17 KLÍMA, J. Lex Rhodia de iactu. Praha, 1923, p. 5.

18 PERNICE, A. Parerga. Ueber wirschaftliche Vorausetzungen romische Rechtsatze. Savigny Zeitschrift für Rechtsgeschichte: Romanistische Abteilung, 1898, Vol. 19, no. 1, p. 84.

19 KLÍMA, J. Lex Rhodia de iactu. Praha, 1923, p. 6. 
formation of a certain community among individual endangered merchants. E. Chevreau names this community as a société de risque ${ }^{20}$ and, as a result, the claims of those whose goods have been thrown out can be settled. Roman law was not influenced by Greek law enough to allow formation of a société de risque, but this use of foreign law is entirely in intentions of bilateral relations of the rental contract. Thus, Roman law rejected the whole idea of collective responsibility, based on a society (société) mutually insuring all the risks of voyage. This idea of collective responsibility hindered the obstacle that, under Roman law, no one could be forced to participate in a social contract (societas) or could be forced to co-ownership (condominium).

\subsection{Secondary Questions of the Rhodian Law}

However, Roman lawyers were not satisfied with the mere application of the Greek principle and they extended the term of "iactus" (throwing out of the ship). In the opinion of his predecessors, Servilius, Ofilius and Labeon, Paulus claims that the duty of the contribution will apply not only to the ship's salvage from wreckage, but also to the payment of ransom for pirates (D. 14.2.2.3). Interestingly, if the pirates entered the ship and seized goods to the merchants themselves, M. Bartošek thinks that the whole situation would be judged as vis maior "and every passenger would have to bear his own damage". ${ }^{21}$ This fragment is the basis for distinguishing a general average (l'avarie commune).

\subsection{Lex Rhodia within ius commune ${ }^{22}$}

Development of this legal institute continued in the Middle Ages where it influenced particularly the maritime law and then reflections about the sharing the common risk as well. Over the following centuries, there was a discussion recognizing that the issue was a responsibility similar to contractual responsibility. ${ }^{23}$ In the context of this discussion, Cuiaccius ${ }^{24}$ considers that the purpose of Lex Rhodia is what Paulus, a Roman lawyer, defined: "Aequissimum enim est commune detrimentum fieri eorum, qui propter amissas res aliorum

20 CHEVREAU, E. La Lex Rhodia de iactu. Un exemple de la reception d'une Institution Étrangére dans le droit romain. Tijdschrift voor Rechtsgeschiedenis 2005, Vol. 73, no. 1-2, p. 75.

21 BARTOŠEK, M. Encyklopedie ř́mského práva [Encyklopedia of the Roman Law]. Praha, 1981, p. 264. For further reference for Roman Law see also STEIN, P. Fault in the formation of contract in Roman law and Scots law. Aberdeen, 1958, p. 122; For modern law see McKENDRICK, E. Force Majeure and Frustration of Contract, 2013.

22 ZALEWSKI, B. Creative interpretation of Lex Rhodia de iactu in the legal doctrine of ius commune. Krytyka Prawa, 2016, Vol. 8, č. 2, pp. 173-191.

23 DAJCZAK, W., T. GIARO, F. LONGSCHAMPS de BÉRIER and P. DOSTALÍK. Rimsképrávo. Základy soukromébo práva [Roman Law. Foundations of the Private Law]. Olomouc, 2013, p. 369.

24 CUIACCIUS, J. C. Opera omnia V. sive Praestantissimi Opera Omnia in decem tomos distributa... tomus quintus vel secundus Operum postumorum quae de iure reliquit sive Iulius Paulus, id est ad Julii Pauli libros ad Edictum, \& Libros Questionum, 1722, p. 531. 
consecuti sunt, ut merces suas salvas haberent." 25 As a base of Rhodian law the part must be considered when the storm or strong wind cause a need to relieve the ship for its salvage and for averting the common danger and the goods are thrown out. This loss resulting from the thrown goods is supposed to be compensated (sata) by the common contribution of the owners of all things whose goods or articles were saved.

Goods are thrown out by magister navis or by some of the owners of the transported goods, or by all owners together. If the goods were thrown out by the owners themselves on the base of a common decision, then according to Cuiaccius it would be better to consider the sue by order, however the use of this sue is hindered by the fact that they did not act with the intention to execute someone's order. Therefore, it is right for those owners whose goods were thrown out to sue the shipowner, and he would sue the owners whose goods were saved so that they provided a part of compensation (pro rata sarcire damnum jacturae dominis jactarum mercium). ${ }^{26}$

He also considers as incorrect an opinion that the obligation of contribution also arises (yet more generally) when, for a purpose to prevent the spread of fire, the neighbours destroyed the neighbouring building for fear of burning their homes so that the fire did not spread and did not pass through it. It is necessary to compensate for the damage caused to the destroyed building owner by that one who is the owner of the saved buildings. This sue will not be allowed in case the buildings were pulled and the fire was extinguished before it reached the buildings that were pulled down (to prevent a fire). In this case, the neighbour would be forced to pay damages using the quod vi aut clam interdiction. If the fire had reached the same level, the man whose buildings were burned would have no sue against his neighbour, as well as there is no sue for the owner whose goods were thrown out of the ship if they acted for a fair cause, that is, if the goods that were thrown out loaded the ship much more than their goods.

He also comments some of the minor issues that were solved in Roman law in relation to lex Rhodia: he excludes the use of sue for the action without order because the defendant owners did not throw out their own goods to save the others but after a common meeting and due to the order of all those who sailed on the ship. According to him, the obligation of contribution is there also for those passengers who have on board only items that do not load the ship, such as rings or pearls, as well as those passengers who do not have a transport contract with magister navis. Cuiaccius also reminds that the magister navis has yet another way, besides the sue, as Paulus says, which can provide a contribution: retention law. Thus, to those passengers who have goods the shipowner will retain these goods on board; those who have nothing he will sue with actio ex locato.

25 D. $14.2 .2 \mathrm{pr}$.

26 CUIACCIUS, J. C. Opera omnia V. sive Praestantissimi Opera Omnia in decem tomos distributa... tomus quintus vel secundus Operum postumorum quae de iure reliquit sive Iulius Paulus, id est ad Julii Pauli libros ad Edictum, \& Libros Questionum, 1722, p. 531. 
We can therefore summarize that Cuiaccius understands the duty of contribution as an obligation to avert a common danger, that this obligation is of a contractual nature. At the same time, however, he extends the obligation of contribution to those cases when the passenger does not have a contract. He also knows the possibility to sue the action without order but excludes this possibility. He also reflects the ongoing discussion of extending ex lege Rhodia sue to cases of extreme emergency but refuses this possibility himself - there is no action against a person who in the extreme distress destroyed other people's things because he acted for fair cause.

\section{Lex Rhodia in the Prussian Land Law and Codex Theresianus}

The Rhodes law wasn't also unknown to the creators of the first Draft of the Austrian Civil Code, known as Codex Theresianus. Codex Theresianus deals with the Rhodes principle in two places - Cod. Th. III, 5, 57-59 and Cod. Th. III. 20, 45-68.

Even more detailed is the legislation of Lex Rhodia in the Prussian Code, which is referred to as ALR. This work deals with the legislation of the Rhodes Act (ALR 2, 8, 1766-1930). The basic outline of this legislation remains the same as in Roman law. A strange thing must be thrown into the sea on the basis of a storm, hostile pursuit, other emergency at sea, and the ship must be relieved. ${ }^{27}$ Only such jettison gives rise to a claim for compensation, which is prompted by the shipowners or is based on their direct order. ${ }^{28}$

On the contrary, Prussian legislation differs from Roman law in that it considers the relationship between a ship and its cargo to be a special kind of community. ${ }^{29}$ This kind of community was discussed in the Greek legal tradition and it is called by E. Chevreau as societé de risqué. In the event that any goods are lost during the journey, the community is transformed into an "average community" ("Havariengemeinschaft"), retrospectively from the moment the goods are loaded on the ship. ${ }^{30}$

\section{Lex Rhodia in Austrian and Czech Civil Law}

F. von Zeiller, creator and author of the commentary on ABGB in 1812, declares that the provisions of $\$ 1036-1044$ ABGB is based on the so-called Rhodian principle, which applies in \ 1036-1042 more narrowly, in \ 1043 and \ 1043 in full. ${ }^{31}$

$27 \int 1795$.

$28 § 1796$.

$29 \$ 1766$.

$30 \int 1768$.

31 Von ZEILLER, Franz Edler. Commentar über das allgemeine bürgerliche Gesetz̧buch für die gesamten Deutschen Erbländer der österreichischen Monarcbie. Bd. III. Wien: Geistinger, 1812, p. 333. 
According to F. von Zeiller, this originally Greek principle of lex Rhodia is already reflected in Roman law, especially with regard to maritime danger. F. von Zeiller directly cites D. 14.2, but at the same time he admits the possibility of applying this principle outside the maritime area - as an example of ransom paid to robbers or ransom, which is paid to the enemy army in exchange for saving the city from plunder. ${ }^{32}$

Another such application of this principle is the use of a another person's property in order to save a thing in need. In this case, the obligation of those whose property has been saved through the use of a foreign object arises in proportion to contributing to damages. ${ }^{33}$

Rudolf von Thering, too, believed that the Roman lex Rhodia was merely an application of the general principle that we can derive from equity ("Gerechtigkeit"). ${ }^{34}$

According to Ernst Swoboda, the basic element that distinguishes the lex Rhodia from other regulations concerning the use of an other person's property is the concept of common danger. ${ }^{35}$

E. Swoboda agrees with F. von Zeiller that this is an example of reception of the Roman law, but points out that there has been a considerable expansion of the field of application of this principle. E. Swoboda understands the lex Rhodia as an exception to the prohibition of interference in foreign affairs. That principle is reflected in $\int 1035$ of the ABGB. The reason why it is possible to intervene is in an emergency, as in $\$ 1036$ ABGB. According to E. Swoboda, the essential defining feature is the common danger and the fact that this common danger threatens not only him but also others. Another difference between the lex Rhodia and a negotiorum gestio is that the gestor cannot be prohibited by dominus negotii. This is because the gestor also acts in his own interest.

Unlike negotiorum gestio, the helper (averter, simply the person who is preventing the damage) not only cares about another person's property, but also protects his own property, so he is only entitled to a relative compensation.

The outcome of a sacrifice of another thing must be the prevention of the moderate damage. According to E. Swoboda, the helper's conduct must be successful. Only in the case of averting damage does the person whose thing has been sacrificed claim

32 Von ZEILLER, Franz Edler. Commentar über das allgemeine bürgerliche Geseţ̧uch für die gesamten Deutschen Erbländer der österreichischen Monarchie. Bd. III. Wien: Geistinger, 1812, p. 334.

33 Ibid., p. 334.

34 Von IHERING, R. Die Reflexwirkung oder die Rückwirkung rechtlicher Thatsachen auf dritte Personen. In: Jahrbücher für die Dogmatike des heutigen römischen und deutschen Privatrechts Bd. 10, pp. 387-586. About this Iherings attitude see WAGNER, G. and R. von Iherings. Theorie des subjektiven Rechts und der berechtigenden Reflexwirkungen. In: Archiv für die civilistische Praxis, 193 Bd., Heft 4, 1993, pp. 319-347.

35 SWOBODA, E. In: KLANG, H. (ed.). Kommentar zum Allgemeinen bürgerlichen Gesetæbuch. Zweiter Band. Zweiter Halbband, $\int 859$ bis 1089. Wien: Druck und Verlag der Österreichischen Staatsdruckerei, 1934, pp. 938-941. 
for damages. The owner must always be eligible. This does not mean, however, that only the owner of a thing has to sacrifice the thing if the victim belongs to a person at risk of common danger.

Very interesting is the observation of E. Swoboda, who systematically classifies $\int 1043$ not as unjust enrichment, but understands it as a special case of versio in rem.

E. Swoboda states, that we can find some other provisions of ABGB with the application of the Rhodian principle. For instance, $\int 837$ shows some similarity to $\int 1043$, but in this case there is no common danger.

In the frame of $A B G B$, Lex Rhodia does not only cover cases of maritime disasters, but may also apply to cases where the one of the owners has insured the property without the consent of the other owners. If the property is damaged as a result of a vis maior, he is entitled not only to the payment of the sum insured, but also to claim from the other co-owners a proportional part of the premium already paid. He has this claim even if he has concluded the insurance contract against the will of the other co-owners Tradition of the Greek Maritime Law Institute appears in the Austrian Civil Code $(\$ 1043$ ABGB). ${ }^{36}$ According to Sedláček ${ }^{37}$, the provision of \ 1043 ABGB was based on "the first sentence is only very closely related to this historical basis." ${ }^{38}$ From originally the only maritime adaptation, the general danger to both the plaintiff and the defendant remained, and then the fact that the plaintiff sacrifices something from his property to avert this danger. Sedlácek associates this institute with the necessary action (\$ 1036 ABGB). The fundamental difference, however, is that the necessary agent acts in favour of the domina negotii, while the one who sacrifices part of his property follows also his own interest, it means saving of the remaining part of his property.

Lex Rhodia was also discussed during the work on the new Czechoslovak Civil Code. ${ }^{39}$ The Draft of 1931 included the provisions of \942, which takes over the principle of lex Rhodia de iactu - if greater damage is averted by sacrifice, the victim has the right to proportional compensation. Unlike $\mathrm{ABGB}$, the common danger requirement, which E. Swoboda considered to be a condition sine qua non of the provision of $\int 1043$ $\mathrm{ABGB},{ }^{40}$ was deleted.

36 WESENER, G. Von der Lex Rhodia de iactu zum \1043 ABGB. In: LUTTER, M. et al. (eds.). Recht und Wirtschaft in Geschichte und Gegenwart. Festschrift für Johannes Bärmann zum 70. Geburtstag. München: C. H. Beck, 1975, pp. 31-51.

37 SEDLÁČEK, J. Nepravé jednatelství a versio in rem. Výklad na $\int 1035-1044$ obč. záke. spolu s rozborem praxe nejiyyšribo soudu [False Acting and versio in rem. Interpretation of $\$ 1035-1044$ together with the Analysis of Interpretation of the Supreme Court]. Brno, 1933, p. 91.

38 Ibid.

39 For the process of making the new Czechoslovak Civil Code in the inter-war period see recently SALÁK, P. Historie osnovy občanského zákoníku z roku 1937. Inspirace, problémy a výzyy [History of the Draft of Czechoslovakian Civil Code of 1937. Problems, Inspirations, Challenges]. Brno, 2017, pp. 9-38.

40 Available at: https://www.senat.cz/informace/z_historie/tisky/4vo/tisky/T0425_10.htm 
The requirement of the common danger, on the other hand, contains another draft of the 1937 outline, ${ }^{41}$ although the government's structure of the draft of 1937 Civil Code, which never came to life, does not refer directly to the lex Rhodia, but it remembers reimbursing the cost and payment (up to ten percent) to the one who saved somebody else's property from "probable devastation or loss". The influence of Roman law can also be seen in the fact that the right is conceived as a retention right. ${ }^{42}$ The explanatory report shows that the coastal law ( $\int 160$ and $\ 388$ of the ABGB) was deleted with justification that it relates only to the seashore and on the banks of the river it suffices only with the found property. ${ }^{43}$

This government draft received another post-war elaboration - it is denoted as Draft of 1946. The provision concerning the lex Rhodia was incorporated into it unchanged. ${ }^{44}$ The Roman Institute of lex Rhodia de iactu was recruited into a concise provision of $\$ 3014$ the new Czech Civil Code: "If one is sacrificing something in need to avert more damage, anyone who benefits from it will give the injured party proportionate compensation." Contemporary comment to the Czech Civil Code rightly claims that $\int 3014$ is based on the Roman lex Rhodia de iactu (and cites in this context the textbook of the Roman law by O. Sommer), but has already "become self-sufficient" and applies to "a variety of cases of sacrificing someone else's property in emergency, unrelated to maritime transport, respectively shipping at all". ${ }^{45}$ The comment cites foreign (Austrian) literature, which permits the use of $\int 1043$ of ABGB in road transport. ${ }^{46}$ Please note in this context that there is a judicial decision, which recognizes the application of the Road Transport Act preferable to the above-mentioned provision. $^{47}$

Basically, there occurs an identification of \3014 OZ 2012 with the institute of Extreme Emergency, which is regulated individually in provisions of $\int 2906$ OZ 2012. As the main difference between the provisions of \ 3014 OZ 2012 and \ 2906 OZ 2012 the comment suggests that in case of extreme emergency, the consequence must not be equally serious or even more serious than the damage that threatened, while provisions of \3014 OZ 2012 speak about avert of more damage.

41 Available at: https://www.senat.cz/informace/z_historie/tisky/4vo/tisky/T0425_31.htm

42 See $\int 152$ of the Government's Draft of the Czechoslovakian Civil Code from 1937. The original document available at: https://digi.law.muni.cz/handle/digilaw/7035?fbclid=IwAR1 raUvZSU2XK8ojS9D6kYV_Rdml1MORF2C_O1XuaXCuroj2mCRAG4Pl-04 [cit. 21. 7. 2019 15.20].

43 Confer also the Explanatory Report to the Government's Draft of the Czechoslovakian Civil Code from 1937 , p. 266

44 LUBY, Štefan (ed.). Československý občiansky zákonník a slovenské súkromné právo [Czechoslovakian Civil Code and the Slovak Private Law]. Právny obzor, 1948, no. 31, pp. $120 \mathrm{ff}$.

45 HULMÁK, M. In: HULMÁK, M a kol. Občanský qákoník. VI. Závaqkové právo. Zvlástní cást (』 2055-3014) [Civil Code. VI. Law of Obligation. Special Part (§ 2055-3014)]. Praha: C. H. Beck, 2014, p. 2008.

46 KOZIOL, H. et al. Kurzkommentar zum ABGB. Wien, 2010, \ 1044, marg. no. 1.

47 WESENER, G. Von der lex Rhodia de iactu zum \ 1043 ABGB. In: Festschrift Bärmann, 1975, pp. 35ff. 
This identification of the lex Rhodia with the institute of extreme emergency has a major impact on the interpretation of the cited provision. Because of this identification, the commentary gives the possibility to compensate the damage in case where "the averter sacrificed the property only for the benefit of another person". 48 If the "averter" sacrificed his own thing, then provision of $\ 3014$ would not be applied, but it would be the non-ordered acting.

Next, there is allowed the payment for damage according to $\int 3014$ OZ 2012 if the damage will be caused on things that do not cause danger. An example of this use of the lex Rhodia is pulling out the pale from the fence and its use for defense against a dangerous animal. If we are to evaluate the provisions of $\int 3014$ OZ 2012, we consider that the basic deficiency is deletion of the term common danger or common need (as is known by the Czech Civil Code of International Trade ( $\int 717$ ZMO 1963) ${ }^{49}$ It is this sign that distinguishes between the extreme need and sacrifice of things in common danger. In addition, the two institutes have a different base.

The discussion about the nature of the $\int 3014$ OZ 2012 continued. There is a variety of different meanings.

K. Eliáš mixes versio in rem and lex Rhodia together as examples of so-called "false acting" (unachte negotiorum gestio, ${ }^{50}$ actio negotiorum gestio utilis), eg. if someone uses a foreign matter and reasonably believes that it's his own thing. Cases traditionally referred to as lex Rhodia are understood by K. Eliáš as being different from both damages and unjust enrichment cases. ${ }^{51}$ On the other hand, A. Pavlíček, who was the only one to deal in detail with the issue of unjust enrichment, understands versio in rem as a subtype of unjust enrichment. ${ }^{52}$

As Kindl states in his brand-new commentary of the Czech Civil Code (edited in the June 2019), this new Czech regulation doesn't apply in the case of maritime transport, because there are already two special acts in force (regulating both river navigation and sea transport). At the same time, he considers that $\ 3014$ should be applied to accidents

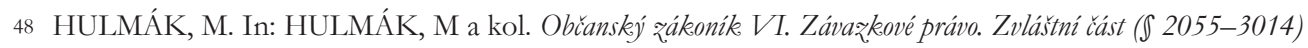
[Civil Code. VI. Law of Obligation. Special Part (§ 2055-3014)]. Praha: C. H. Beck, 2014, p. 2008.

49 This Code was issued in 1963 to serve the needs of foreign trade. Therefore, it is much less affected by communist ideology and much more preserves the institutes taken from Roman law. For the codification of private international law see RƯŽIČKA, K., B. POLÁČEK and P. DOSTALÍK. Geneze kodifikací mezinárodního práva soukromébo. Soukromoprávni úpravy męinárodnich pomérü [Genesis of Codifications of the International Private Law]. Praha: Leges, 2019.

50 ZIMMERMANN, E. Echte und Unächte negotiorum gestio. Giesen, 1872, passim.

51 ELIÁŠ, K. et al. Nový občanský zákoník s aktualizovanou di̛vodovou zprávou a rejstríkem [The New Czech Civil Code with Explanatory Notes and Register]. Praha: Sagitt, 2017, p. 1064.

52 PAVLÍČEK, A. Žaloby z obohaceni vedle rakouského práva občanského se zulástním žretelem k právu obecnému, k áákonim i nástinum modernim [Condictiones of the Unjust Enrichment according to Austrian Civil Law with the Hindsight to the Ius commune, the Other Civil Codes and Drafts of the Civil Codes]. Praha: Jednota českých právníků, 1873, p. 124. 
that are not related to maritime transport, eg in the case of a balloon or airship. It also outlines the possibility of applying this provision in out-of-accident situations that are close to extreme emergency. As a model case the blasting of the house is mentioned in order to block the watercourse during flooding. ${ }^{53}$

As Melzer in another commentary says, the provision of 3014 OZ 2012 is a bit "enigmatic," 54 however, it is certain that this provision is based on the principle of "no one can enrich at the expense of another" and is therefore a special case of unjust enrichment (along with specificatio, aluvio, accesio and versio in rem.). It contains elements that are typical of lex Rhodia de iactu - such as sacrificing things in need, averting greater danger or proportional compensating for damages. At the same time, however, the requirement of a common danger has been deleted, which means that this provision can be understood as a special case of extreme emergency. ${ }^{55}$

In conclusion we can state, although in Czech law there is reception of this traditional provision of Roman law, the Czech jurisprudence separated (in response to the Austrian private law school) lex Rhodia from its traditional maritime role and is looking for the new possibilities of use for this institute.

This possibility opens up in Czech legal science by deleting the concept of common danger from the definition of $\int 3014$ OZ 2012. This minor textual amendment is intended to make this institute independent. The Czech legal science discusses the possibility of using this institute for damages, which is caused to third parties in averting the danger within the framework of the institute of extreme emergency ( $\int 2906$ OZ 2012). Compensation for the deterioration of danger in extreme emergency was admitted by older literature, ${ }^{56}$ but with the help of a negotiorum gestio. However, with such a wider application of the lex Rhodia de iactu, we come across other legal institutes which have also been taken over from Roman law such as versio in rem (\$ 3012 OZ 2012) or "false acting" (negotiorum gestio utilis: \3013 OZ 2012). In this context, in my opinion, it is necessary to consider the possibility of placing these cases of sacrifice under unjustified enrichment in the broader sense ("liability outside condictiones"), which is allowed by the re-construction of unjust enrichment in the OZ 2012 (\ 2991 (1) OZ 2012).

53 KINDL, M. et al. Občanský zákonik. Praktický komentár. 2. Svaz̨ek. [Civil Code. Practical Commentary] Plzeň: Aleš Čeněk, 2019, p. 877.

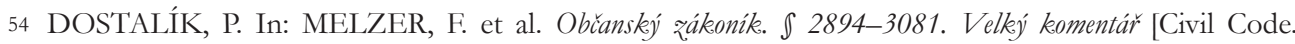
\2894-3081 Grand Commentary]. Praha: Leges, 2018, p. 1639.

55 Ibid., p. 1640.

56 LUBY, Š. Prevencia a zodpovednost’v obrianskem právu. I. [Prevention and Liability in the Civil Law]. Bratislava: Vydavatelstvo Slovenskej Akadémie Ved, 1958, pp. $321 \mathrm{ff}$. 